\title{
How Can Education Managers in Secondary Rural Schools Generate Funds within a School-Based Management Framework?
}

\author{
V.C. Ngwenya \\ Department of Arts and Education Zimbabwe, Open University, \\ Bulawayo Region, P O Box 3550, Bulawayo, Zimbabwe \\ D. Sibanda \\ Nongoma, Box, 1552 Nongoma 3950, KZN, South Africa.
}

\begin{abstract}
This paper reports on how education managers in rural secondary schools may generate funds informed by the school-based management framework as financial management in Zimbabwean schools has been decentralised to school level. Looking at the school system on a continuum, on one end there are first class schools which have well developed infrastructure and are well resourced. On the other extreme, there are dilapidated and scantly resourced ones. However, within this scenario, there are some affluent rural schools depending on the responsible authority which can compete comparatively with their urban counterparts. This paper focuses on the critical role of the educational manager in resource mobilisation assisted by willing internal and external stakeholders, philanthropic foundations included. Since the bulk of the parents are peasant farmers, who rely on rain-fed agriculture, education managers are advised to link up with the external community for additional funding if human capital, so much needed by both the education sector and corporate world is to be developed. The study employed a qualitative approach of a case study design involving semistructured face-to-fact interviews with purposefully selected participants comprising an education manager and four teachers. A small sample was considered ideal for an indepth study of the phenomenon. Data collected was triangulated and verified with the participants for accuracy and credibility. The findings suggested that the volatile economic environment education managers operate in points towards soliciting funds from external stakeholders as part of their turnaround strategies. Armed with the appropriate strategic plan a rural school may resemble an oasis in the desert. We conclude that schools in impoverished environments should look elsewhere for funding. Equally important is the fact that as researchers, we are conscious of the fact that our cross-sectional study is based on qualitative data which may limit the generalisation of such findings to a different context.
\end{abstract}

Key words: Accountability, Foundation Board, Reporting structure, School Finance Policy, Finance Sub-Committee, Stakeholders.

\section{INTRODUCTION}

At independence in 1980, the Zimbabwe African National Union Patriotic Front (ZANU PF) government, placed education within the fundamental rights for every individual child by adopting the education for all (EFA) policy (Education Act, 1987) [1]. This socialist driven ideological thrust was meant to redress the social injustices which existed in the past (Zvobgo, 2004) [2]. Consequently, it triggered a social demand for education among the populace to unprecedented phenomenal levels with admission in rural secondary schools becoming difficult to accommodate. The EFA policy was in compliance with the United Nation's goal of 
Universal Primary Education (UPE) of 1948 and was based on the assumption that education for an underdeveloped nation such as Zimbabwe would be a panacea for economic development through human capital investment. However, the economic realities of the $90 \mathrm{~s}$ ushered in levies and tuition fees as citizen participation was sought in the educational arena (Education Amended Act, 1991) [3]. This led to the establishment of the School Development Community [SDC] (Statutory Instrument 87 of 1992) [4] and School Development Association [SDA] (Statutory Instrument 73 of 1993 [379 of 1998]) [5] in schools, not for infrastructural development only, but to fund education within the school-based management framework. The removal of government subsidies as prescribed by International Financiers brought about financial challenges to both public and rural secondary schools (Masvora, 2016) [6]. Faced with such a mammoth task against scarce resources, education managers in rural secondary schools were tuition is charged lower than their urban counterparts as equity considerations are sought (Government of Zimbabwe's School Regulations [GZSR], 2011) [7] are left with no choice save to argument their dwindling school coffers through various legal income generating projects or fund raising activities within the school-based management framework (Kruger, 2002) [8].

\section{BACKGROUND TO THE STUDY}

Many Zimbabwean rural secondary school education managers are faced with the demanding task of providing quality education in a hyper-inflationary climate. The clientele are demanding value for their money against inadequate resources and education managers are left with no choice save to place more and more emphasis on fundraising (Gentile, 2009) [9]. The strategies which many organisations adopt as a means to seek alternative revenue sources are purported to entice the donor community back to the schools despite governments attempt to wean them from this donor-dependence syndrome. As rural schools experience a decrease in funding from traditional sources, there is need for education managers to seek alternative sources of generating revenue at micro-level as powers to manage funds have been decentralised to school level [4] and [5]. While urban schools may raise tuition fees at willynilly with the concurrence of the Secretary for Education, because their catchment areas are populated by the working class, rural schools are different (Cohen \& Brawer, 2008) [10]. Most of them survive on shoe-string budgets because the bulk of the guardians or parents are peasant farmers who rely on rain fed agriculture, which in the face of Elinino induced drought, such schools are characterised by non-payment of fees. Although according to the statute on the collection of fees both the SDC and education manager are mandated to exclude learners who would have failed to meet their financial obligations, the same statute advises them to seek concurrence with the Secretary for Education [7] for such a financial decision to be made. This leaves most of the rural secondary school coffers in the reds, hence, compromising the effective delivery of the education service.

There are a number of alternative revenue sources rural secondary schools may pursue but, the abrupt withdrawal of potential donors in the funding of education as recommended by the International Financiers [6] coupled with economic sanctions may have dare consequences if not checked. While it is easier for their urban counterparts to increase fees as they see it fit with the concurrence of the Secretary for Education, in rural schools, the story is different. Whatever, proposals they make, they need to consider the affordability level of the community as there could be the danger of running either half-full or empty institutions which would be in breach of the Constitution of the Republic of Zimbabwe [CRZ] (2013) [11]. On the other hand, not all schools have the same capacity for fundraising as they have different socio-economic backgrounds. That is the reason why some schools in the same geographical locality are succeeding yet others are having difficulties of having well resourced institutions. Yet with the 
right leadership, all schools have at least the capacity to secure private funds. Success on one hand may depend on the extent to which fundraising is handled as part of the institution's overall rural relations effort through its school financial policy, while on the other, the way it is assigned, coordinated, and the strategies used to ensure returns on investing on such campaigns are well reported [10].

Rural secondary schools, like all educational institutions, are facing a funding crisis as the school-based management framework takes its toll. As [10] note, funding for rural secondary schools is quite variable and complex. There is no perfect formula or solution that would meet each institution's needs. However imperfect, the funding structures may be, it may either enhance or hinder a school's ability to serve the interests of learners in full measure. As from independence to the 90s, government subsidies and donations could be counted on as a foundation to support the mission of rural secondary schools in their attempt to offer affordable, open-access education to the communities they served. However, the recent cuts in state expenditure on schools in general and rural secondary schools in particular, have compelled education managers to look elsewhere for funding. The majority of rural secondary schools are engaged in alternative revenue sourcing even though they are struggling to meet their targets. To cushion them from the effects of the devastating drought coupled with the economic meltdown, the Zimbabwean government sources donations on behalf of the marginalised communities referred to as the School Improvement Grant [SIG] (Matimbe, 2014) [12]. The bulk of this fund is meant for capital development and is not all rural secondary schools who benefit from it as more of it is concentrated in the provision of basic education. In this context, education managers are called upon to be at the forefront of revenue generating activities meant to source teaching-learning resources if the education enterprise in rural secondary schools is to remain effective.

In the past most schools have been engaged in traditional income generating projects such as rearing of chickens and growing of vegetables [12]. These brought about the problem of labour sometimes and theft included. On the other hand, rain-fed income-generating projects were devastated by the chronic droughts which have hit Southern Africa of late. Alternatively, enterprising schools brought in innovative ideas such as selling cakes, sewing and selling uniforms, sponsored spelling/walk, leasing of school rooms/hall and grounds for special occasions including running the tuck-shop[12]. Of late some enterprising schools manned by dynamic education managers are engaged in twining endeavours. However, to arrest the astronomical costs of running a school in a hyper-inflationary environment, schools came up with the quickest fix for settling utility bills as they came or to offset some operational costs, through the famous and infamous civvies. According to the statutes on fundraising activities, only one such activity is allowed per year, any other, it should be in concurrence with the Secretary for Education (Treasury Instruction [TI], 1992) [13]. However, schools in defiance of this piece of legislature, civvies had become a routinised ritual on the school fundraising calendar as they tried to meet their financial obligations. Some overzealous education managers in league with the SDC Chairpersons went to the extent of excluding learners for non-payment of civvies charged regardless of their financial status. Government on the other hand considered such a practice as an infringement on the basic fundamental rights of an individual [11]. The [7] are very clear on this aspect as they demand that vulnerable learners should not be discriminated, exploited, victimised or humiliated in pursuit of such activities [12]. As a result of the wanton exclusion of learners which had characterised schools by then, parents clamoured for the total abolishment of the practice. Coupled with the rampart abuse of such funds by the school authorities, SDCs and bursars as reported in the weekly (Harare 
Bureau, 2016) [14], the Ministry's response was in consonance with the parents' sentiments. The Ministry thought schools were neglecting their core business of teaching in pursuit of generating funds under the guise of fundraising [12]. After that schools were left in a quandary. In that view, other avenues of fundraising had to be explored as SDCs and education managers were being given increased managerial autonomy through financial management which had been decentralised to school level [4].

\section{The Education manager's Leadership Role}

Faced with the challenges of declining state funding and the prospect of high tuition increases, fundraising at school level has certainly been raised in importance and prominence over the last decade. Nearly every rural secondary school has now joined the call for additional fundraising in contradiction of the Ministerial directive on such activities [7]. With its new found prominence comes more attention and research towards fundraising issues.

In the mid 1980s, Ryan (2003) [15] an advocate of fundraising activities in schools viewed the education manager as a critical factor in the process. First, and foremost in his view, it is incumbent upon the education manager to be actively involved in the generation of school funds. Beyond simply participating in the process, [15] notes that the responsible authorities should recognise the time and commitment school authorities spend on fundraising efforts. Secondly, successful schools spend money on their fundraising efforts in order to raise money. The irony of the latter opinion is that rural secondary schools cannot spend the little money they have; instead they would need $100 \%$ sponsorship in every fundraising activity they engage in.

Among many issues, schools need strong leadership from their education managers in order for them to be successful in fundraising. School managers should take a leadership role in their school by effectively communicating their need for funds as they are regarded as Chief Accounting Officers (CAO) in their own right in the organisations they operate in (The Public Finance Management Act [PFMA], 2009) [16]. Glass and Jackson (1998) [17] examined the specific roles an education manager must play, the leadership style which would best fit those roles, and the degree to which other institutional players, like board and foundation members, have in the fundraising process. The study revealed that education managers have four main leadership responsibilities. Firstly, they must communicate the vision of the organisation. Secondly, garner support from their board, staff, and departments. Thirdly, they must lead by example by committing time and money to fundraising efforts. Fourthly, they must develop fundraising budget plans and initiatives. This is so because education managers by virtue of their positions can actively shape the community expectations of the school, solicit cooperation and support for their activities and build a public image (Everard \& Morris, 1996) [18]. As they fulfill these roles, education managers must be on the forefront of the fundraising team by articulating the goals clearly and helping participants understand their roles in the fundraising structure. Above all, they should be able to synchronise all the actions, means and techniques within the school (Bisschoff, 1997) [19].

[9] study further acknowledges that education managers are taking a leadership role in seeing the school through tough economic times by trying to develop alternative revenue sources. It also reveals that they are also attempting to absorb the financial losses caused by the reduced government expenditure in schools. Although fundraising was an alternative option for generating money, most education managers did not see is as a viable avenue for such funds amid the economic realities they were operating in. Consequently, education managers 
preferred to play an ambassadorial role on behalf of rural secondary schools as they sought potential donors, an equally insurmountable task.

Satterwhite (2004) [20] set out to study the education manager's role in this important facet of school revenue development. His findings revealed that the education manager's roles included: involvement in strategic planning, interaction with external constituents, developing high-functioning teams, working effectively with internal staff, coordinating the institution's fundraising efforts, and ensuring that the institution has adequate fundraising resources. Slinker (1988) [21] corroborated these views by asserting that education managers set the tone and vision for the advancement office, make sure that it has reasonable goals, funding to meet those goals, and establish positive relationships with donors, alumni, and governmental officials. These leadership functions of the education manager as a financial manager boil down to three aspects, namely: "sound relationships, motivation of all people concerned with school finances and communication with all the stakeholders, internal as well as external" [19, p 99].

\section{Developing and maintaining relationships with potential donors}

Successful relationships in fundraising activities rely on harmonious collaboration among learners, academic staff, administration and prospective donors if financial objectives of the school are to be achieved [19]. Such relationships need to be developed and cultivated as well. Internal relationships are linked to delegation within the context of the school financial policy. The education manager should outline duties and delineate tasks accurately within the dictates of the legal financial statutes [16]. Most importantly, the hierarchical structure of authority, authorisation for various expenditures, the financial procedure of expending money and to whom the results of the expenditures must be reported to should be availed to the staff members involved in fundraising activities to avoid misunderstandings (van der Westhuizen, 1991) [22].

On the other hand, within the context of the school finance policy, the education managers must cultivate and develop health relations with external stakeholders in the likes of the parent community and the private sector [19]. Such relationships should be nurtured to ensure their continued financial support [19]. However, education managers are warned against abuse of such funds and advised to put transparent accountable procedures if they are to have such funds continuously flowing in the school coffers [19]. This feat is possible if the education manager is equipped with appropriate abilities and skills to form and maintain healthy relationships with the external world, hence the Management course they are undergoing with the Zimbabwe Open University. This view is collaborated by Hall's (2002) [23] study which revealed that for education managers to be able to raise money for their schools through various stakeholders, they should be good listeners and create healthy relationships with both the donor and recipients of such a gift.

Gorton (as cited in [19], 1997, p. 101) in collaboration with the above sentiments, suggested the following techniques meant to improve relationships between the school and the external stakeholders:

- Schools must create conducive environments which enable the community to participate in the school activities,

- Complaints received from external stakeholders must be treated sympathetically,

- Schools must use contact bodies (such as relevant Ministries, local politicians and Nongovernment organisation [NGOs]) as a starting point to gain access to other related bodies or the private sector, 
- The active participation by the school in community activities, and

- Financial feedback mechanisms to the community must be put in place as a way of accountability. [15] concurring with the significance of relationships in fundraising activities found evidence that revealed that significant fundraising gains can be made by cultivating and maintaining relationships with corporations and private philanthropic foundations. His study also admonishes most education managers who celebrate when they get funds from donors and fail to sustain donor relations through failure to present pleasing and convincing feedback in the form of a report. However, despite the above tabulated guidelines, it has been discovered that the predicament that most schools face is lack of financial knowledge or background to raise funds effectively (Carter , 2011) [24], an issue which needs to be addressed if rural secondary schools are to be on a sound financial footing.

\section{Financial school management and motivation}

The actual actions of a school education manager are determined by their personal perspective and thoughts about fundraising and on how they interpret the training that they have. Neumann and Bensimon (1990) [25] identified four types of education managers, each with their own strengths. The first type was externally focused, using those relationships to the benefit of the school, an initiator of action, and connected to the internal school rural. Unlike the first type, the second type was connected to the internal rural and is internally focused. They also initiate ideas and solutions within the school rather than waiting for ideas to be presented to them. The third type was externally focused in relation to identifying relationships that can help the institution in the short term. As such, they are less focused on the internal workings of the institution as they react to needs and attempt to meet those needs with fundraising. The final one focused on internal structures and policies as they control the organisation. Like the previous type, this one also focused on the immediate funding needs and how funds can be raised to meet them.

Taken together, these education manager types represented the different thought processes and contexts within which education managers make decisions. The researchers noted that this is only a guide to the possible assumptions and motivations that influence education managers as they approach fundraising.

Within this scenario, it is incumbent upon the education manager to differentiate his/her motivation strategy in accordance with both the external and internal stakeholders' motives [19]. S/He must be people oriented and take cognisant of the fact that both internal and external stakeholders have divergent needs and their motives for being involved in school activities will differ but need to be sychronised around a collective and shared performance agenda [19]. All players, particularly the parent community must be made to feel that it is their collective responsibility to fulfill the financial objectives of the school, more so that they are the natural and primary educators of the learners and fund the education enterprise [22]. On the other hand, the education manager as the CAO or Accounting Officer of the institution must make the staff members and learners be aware of the economic aspect of the school and the consequences of mishandling the scarce financial resources [19]. Since schools are there to produce inputs in the form of human capital for the community and corporate world, there is need to engage external stakeholders at a reciprocal level according to van Schalkwyk (as cited in [22]). In short, schools need financial support from the business community which they have, to produce the product (human capital) they (corporate world) desire, hence the need to engage in such a symbiotic relationship as advocated for by Wise (as cited in [22]). However, 
the major focal point should be on building conducive relationships with the parent community who in turn would market the school to the larger external stakeholders.

As fundraising has become the heart and soul of schools, the grounds and norms under which professional fundraisers and education managers operate while soliciting donors is valuable (Caboni, 2010) [26]. As observed in Martha Beyers' study (cited in [26]) there were a set of standards that could be applied by fundraisers to ensure that they protect the interests of both the institutions they work for and the donors they solicit. Although there might be a fundraising committee, the field lacks some of the key characteristics that classify a group of workers as professionals. The standards foster ethical behaviour and help protect the donors and the institutions from dishonest actions on the part of fundraisers. Miller (1991) [27] noted that the responsibility for fundraising lies with the education manager, despite the fact that fundraising professionals have a specific role to play. [27] further says, the characteristics of an effective fundraiser are the same characteristics that make education managers effective, which verifies their role as professional fundraisers. These similarities enable them to engage learners and parents for the future benefit of the school all the while working on other fundraising initiatives.

Sygielski (2008) [28] proposed a different view on fundraising techniques that could be employed by education managers. He looked at fundraising from an entrepreneurial perspective and identified what makes a school entrepreneurial. While education managers are expected to bear the brunt of the burden of fundraising as the leaders, visionaries, and motivators behind a school's fundraising efforts, it is not always a welcome task. Little wonder that it is viewed as an inevitable evil. What all this boils down to is that financial management in a school system hinges upon the education manager as a leader in the fundraising process. Such a person needs to develop and maintain appropriate relationships with both the internal and external community of the school. All players will require the appropriate motivation from the education manager for them to channel their energies towards the achievement of the school's finance policy; hence this study which sought to find out how education managers may engage both internal and external stakeholders in their quest for more funding as a schoolbased management framework is adopted.

\section{METHODOLOGY}

A qualitative approach of an interpretative nature utilising a case study design was employed in the collection of data (Creswell, 2014) [29] meant to establish how education managers in Zimbabwean's rural secondary schools generate funds within the school-based management framework. The design was deemed the appropriate method of data gathering because the phenomenon under investigation was exploratory, the boundaries between phenomenon and the context were not clearly evident in which multiple sources of data were employed (Yin, 2012) [30]. This thrust was meant to supplement the traditional methods of fundraising activities which schools have used in the past amidst the volatile environments they operate in. In that light, a single case was selected for an in-depth analysis of the case at a single research site and the major research tool used for this purpose was the interview protocol [29]. Data sourced from the interview was triangulated with that from field notes, observations, legal documents and related literature reviewed (Soy, 1997) [31]. The use of multiple sources of data was meant to validate it (Denscombe, 2007) [32]. To further ensure that data gathered was credible and reliable, the semi-structured interview questions were pilot tested with nonparticipants of similar characteristics [31]. In the light of the experience on the ground, the interview guide was modified and adjusted accordingly. The post interview strategies 
employed to validate the data were member checking of the major findings, themes and the use of a rich, thick description to convey the findings [29]. Since the case is within the boundaries of the context under investigation, researchers were convinced that the findings were beyond the issue of generalisability, hence, making the investigation suspect to issues of external validity [31]. However, generalisability was left to the reader.

The participants of this study and the research site were purposefully selected because of their proximity to the phenomenon under investigation. The former involved: one education manager and four classroom practitioners. Data gathered was first reconstructed and categorised in various chunks according to their relationship [31]. After that the categories of data were cross-checked with the participants for accuracy and where discrepancies were unearthed, the key informants were revisited for verification [31].It is from these categories of data that new themes emerged which became subject for discussion in this study. Considering the way the information was gathered, researchers considered it credible, reliable and valid.

\section{FINDINGS}

The findings were reported under the following themes: leadership roles, maintenance and development of relationships with the donor community and effective fundraising and motivation.

\section{The leadership role of the education manager}

School authorities in rural schools due to the impoverished backgrounds of most of their clientele have to go an extra mile in their attempts to raise funds for their schools. When the informants were asked the various roles education managers should play in the fundraising process, all concurred that as 'visionaries for such institutions', they should aim at establishing a 'Fundraising Foundation Board'[FFB] in their schools [17]. Such a board should be manned by 'innovative' and 'proactive staff members' who are eager to be 'drivers' of such an initiative. All they requested was to be 'staff developed' towards that orientation in line with the 'vision', 'mission' and 'strategic plans of the organisation' [17; 20; 21]. The teachers also believed that for such an initiative to take off on a sound footing there was need for the education manager to establish 'communication networks' which would connect the voluntary staff members to the 'corporate world within their communities' and 'donor community outside the school' through being their 'spokesperson' $[16 ; 19 ; 23]$. Besides being their sounding board, teachers also envisaged an education manager who is 'hands-on' by being actively involved in all the processes of fundraising if the FFB was to be built on a solid foundation [15]. As a way of empowering the fundraising staffers within the education manager's jurisdiction, participants were agreed that there was need for school authorities to 'flatten their organisational structures' and 'democratise them' [19; 22]. In that manner, they believed that power would be 'decentralised' (from the centre) to the staffers (periphery) and 'autonomy' would be the cornerstone as they engage in their operational activities [22].

Although the education manager interviewed concurred with such a set up, he cautioned the staffers to be 'accountable for their actions' [22] in the process so as to protect both donor funds and funds raised from abuse by those handling them $(6 ; 27)$. He further intimated that it was within his legitimate authority to devise 'policy guidelines' for such a board to enable it to operate within the 'juridical requirements of the fundraising statutes' [7; 13]. However, through this interaction, it was observed that the education manager wanted to go solo in coming up with such guidelines independent of the internal stakeholders, a scenario which perturbed the researchers. Encouraging though within this context was that he was in consonant with the concept of establishing support systems meant to continuously develop his 
staff towards that direction. He was even prepared to second willing staff members to renowned organisations outside the school with a traceable record in fundraising without the individuals incurring any expenses.

\section{Developing and maintaining relationships with potential donors}

With both internal and external communication networks linked by the education manager, the participants suggested that the business of fundraising should be delegated to the FFB members. To avoid issues of role conflict and ambiguity, they requested that management outline their duties and delineate their tasks as accurately as possible within the dictates of the legal financial statutes [19]. They went on to suggest that the FFB constitute a a professional fundraising committee made up of a chairperson (who would chair all such sessions, preferably a Head of Department), secretary (to minute all deliberations of such sessions, preferably an English specialist), treasury from the accounting department ( to receive all donations or fundraising activities cash for onward transmission to the School Finance SubCommittee (SFSC) for accountability purposes,) and committee members [preferably from the commercial department] [22]. Depending upon the numbers of the FFB members, two of the committee members who might be having a commercial background may straightway become public relation officers of the Board. For the purposes of linking up the committee to administration, the education manager weighed in by suggesting that the Deputy Head be seconded to such a committee to give it credibility and legitimacy [19] as an ex-officio member. In the long run it was agreed that the secondment would reduce bureaucracy and also save the chairperson a lot of energy of shuttling between the committee and administration for feedback purposes. They also concurred that the selected public relation officers should be eloquent persons who are knowledgeable in the policy directives of fundraising activities of the school as they would need to market its vision to the internal staff and external community $[19 ; 22]$. By external community, they were quick to mention that their first port of call would be the parent community ('businessmen/woman' and 'farmers'), 'the NGOs' 'government departments' and 'politicians' in their immediate community before they would invade the 'urban corporate world' as suggested by Gorton in [19]. When such staffers interact with the potential donors in the external community, the participants suggested that they should be armed with the School Developmental Plan constituting prioritised projects with their costs. All things being equal, it was agreed that for the purposes of accountability, such a committee would be accountable to the SFSC.

With potential donors having been identified, participants believed that it would be in the best interest of the school if such persons would be invited to social functions [19;22] of the school such as 'fundraising activities' and 'Speech and Prize Giving Days'. This would enable them to have a 'feel of the school's poverty level' they are supposed to deal with in terms of its 'needs' and know its 'brand' as well. One of the teachers even went to an extent of suggesting that the 'background of the would-be donor be researched thoroughly' so as to know their spheres of influence. This would assist the school to gear up their activities to the interests of the wouldbe donor. The involvement of FFB members in this manner, in their view, did not make them 'change agents of the school system' only but 'ambassadors' as well who have the mandate to 'market the school to the outside world'[9; 18].

\section{Effective fundraising and motivation}

Of late Zimbabwean schools through school-based management collect different kinds of fees; bank them in their different accounts for future utilisation through the SFSC, of which the education manager as chairperson is the CAO. It is this critical role the education manager 
plays in an institution that participants were asked as to what kind of attributes should an effective fundraiser possess.

All participants responded and their responses were varied. They were all agreed on the fact that education managers in particular, the staffers and parent body in general, should endeavour to cultivate and maintain relationships with the corporate word and private philanthropic organisations [15] build positive relationships with at either a personal or Boardlevel. Although earlier on, this task was delegated to the FFB to make contacts, the participants felt that after the ground work had been laid down, many would-be donors 'felt honoured and respected when they interacted directly with the education manager' $[15 ; 18]$. Teachers went on to suggest that it would be in the best interest of the school if the FFB members were introduced to the external community by the education manager at such interactions to give it credibility and authenticity. According to the informants, this was meant to guard against 'unscrupulous' or 'dubious people' be it teachers or members of the community who would solicit funds for their personal business while claiming to be doing so on behalf of the school [6;27].

In addition to that, teachers felt that education managers needed to be human oriented [19], enterprising and approachable if they were to 'soften the hearts' of both the internal and external community. Such attributes would need to be transferred to the committee delegated to mastermind fundraising activities of the institution as well. The intermingling with the external community in that manner in the participants' perspective was an appropriate recipe for creating fertile ground for future engagements [25]. They also suggested that such interactions should be characterised with a high degree of professionalism [26; 27]. They emphasised that virtues of 'integrity', 'humility', 'honesty' and 'ethics' needed to be exhibited unreservedly at such transactions [26]. They all concurred that such attributes if portrayed in the positive light would no doubt 'soften the hearts' of the prospective donors. The education manager strengthened this argument by weighing in his experience with donors by asserting that, 'prospective donors want transparency when it comes to soliciting funds and dislike shoddy deals' $[15 ; 19]$. It is in this manner that they concluded that with the correct frame of mind, proper orientation and motivation the dream of enticing prospective donors to their institutions would be 'mission accomplished'.

\section{DISCUSSION}

Effective educational schooling in Zimbabwean schools cannot take place in an institution barren of resources and for the teaching-learning resources to be available funds are required. Gone are the days when resources were scarce in schools and a remote authority would be apportioned the blame. It is therefore, within the education manager's legitimate authority as a professional fundraiser [27] to make sure that schools are well resourced if an effective educative enterprise is to prevail within a school-based management framework. This empirical research has revealed that the buck lies in the hands of the education manager. In that light, the mindset, philosophy and orientation of the education manager seems to be the appropriate framework needed in order for him/her to be able to activate all the school systems towards successful fundraising.

The empirical findings have further revealed that within the tough socio-economic environments [9] of a rural secondary school set up, coupled with the chronic droughts Zimbabwe experiences of late due to global warming, it is no longer possible for education managers to rely on the immediate community as most of them are peasant farmers. This parent status seems to be enhancing the dwindling of financial resources in rural schools, thus 
making effective teaching - learning nearly impossible. Although many a time schools are encouraged to adopt self-help strategies [12] as a way of empowerment and weaning them from the donor-dependency syndrome which has characterised the post-independent Zimbabwean era, rural education managers are left with no option save to woe them back to school. Evidence revealed by this empirical research seems to suggest that, the current economic challenges Zimbabwe is experiencing of late demands that there be a symbiotic relationships between the school and the corporate world in the production of relevant human capital as observed by van Schalkwyk in [22]. In that light a proactive and enterprising administration, staffers and immediate community is needed to drive such a vision. Within this scenario, education managers would need to shade off some of their responsibilities through delegation [19] with an intent of establishing high functioning teams [20] which would be at the forefront of such a venture as a way of envisaging a collective responsibility towards the fulfillment of the school's financial objectives [19; 22] and budget plans [17]. In that way if such teams are well oriented towards the school financial policy, different talents individuals are endowed with would be utilised to the fullest. What possibly would be needed in the process would be to have an education manager who is regarded as a critical factor [15) in the fundraising process who possesses a clearly defined school finance policy within the juridical requirements of the financial management statutes $[1 ; 3 ; 4 ; 5 ; 7 ; 13 ; 16]$. This should be adequately and effectively communicated [19] to the internal environment of the school for marketing purposes to the external environment if a holistic approach to fundraising is to be adopted. Most importantly, the reporting structure [22] with transparent feedback mechanisms [19] must be put in place for accountability purposes, thus, making such teams and the school credible. To further enhance its public image [18] to the external stakeholders, education managers need to be always visible to the prospective donors within the schoolbased management framework as additional funding is sought. Equally important is to ensure that whatever fundraising activities are put in place must be internally and externally focused [22] as the two complement each other.

\section{CONCLUSION}

Zimbabwean communities differ in terms of their economic activities and this is evidenced by the different infrastructural backgrounds which have since mushroomed in some rural schools as observed by the researchers. Gone are the days when peasant farmers would be mainly relied on as cash cows for rural secondary schools since most of their rain fed agriculture is chronically affected by the devastating drought which has hit Southern Africa of late. In the face of reduced government subsidies on education, it may be concluded that education managers should look beyond the school boundaries for additional funding if they are not to be redundant and irrelevant.

By the same token, the development and cultivation of positive community relationships by the education manager in both the internal and external community is inevitable. The school vision should be well incorporated in the school finance policy and articulated to all stakeholders as well. Responsibilities should be delegated according to one's potentials, the appropriate skills and orientation should be nurtured and motivation cultivated within this management framework. The school image and finance policy should be well marketed to the external community if rural secondary schools are to resemble an oasis in the rural areas they are located in terms of infrastructural development and resources. In that manner, Zimbabwean rural schools would become beacons of hope as quality education is sought within the schoolbased management framework. However, internal fundraising efforts must not be ignored totally in pursuit of external donors as the latter prefer to assist those with limited resources, 
contrarily to those who approach them empty-handed. Finally, fundamental rights and liberties of learners should not be fringed upon as schools pursue fundraising activities within a decentralised financial management system $[11 ; 12]$.

\section{FUNDING}

This project was self-funded by the researchers and received no funding from the parent university, corporate world and any philanthropic organisation whatsoever.

\section{References}

1. The Education Act: Chapter 25:04. Government of Zimbabwe, Harare: Government Printers; 1987.

2. The organisation and administration of primary and secondary school education. Harare: ZOU; 2004.

3. The Education Act (Amended) : Chapter 25:04. Government of Zimbabwe, Harare; 1991.

4. Statutory instrument 87: Education (School Development Committees) (Non-Government Schools) regulations. Government of Zimbabwe ,Harare: Government Printers; 1992.

5. Statutory instrument 379: Education (School Development Associations) (Government Schools) regulations. Government of Zimbabwe, Harare: Government Printers; 1998.

6. Government excess staff to be retrenched. The Sunday News. 2016;1. (2016, May 8-14).

7. School Regulation. Government of Zimbabwe. Harare: Government Printers; 2011.

8. Managing the school as an organisation. Pretoria: UNISA; 2002.

9. Ensuring the American dream: Perceptions of New Jersey community college education managers on fundraising as an alternative revenue source to preserve access and affordability. (Published dissertation). Nebraska: University of Nebraska-Lincoln; 2009.

10. The American community college (5th ed.). San Francisco: Jossey-Bass; 2008.

11. Constitution of the Republic of Zimbabwe. Government of Zimbabwe. Harare: Government Printers; 2013.

12. Master of education in educational management: Financial management in education. Harare: ZOU; 2014.

13. Treasury Instructions. Government of Zimbabwe. Harare: Government Printers; 1992.

14. New rules for school levies. The Sunday News. 2016;2. (2016, May 15-21).

15. Excellence in educational fund-raising at America's community colleges. Community Junior College Research Quarterly of Research and Practice. 2003; 12(4), 311-327.

16. The Public Finance Management Act. Harare: Government Printers; 2009.

17. A new role for community college education managers: Private fund raiser and development team leader. Community College Journal of Research and Practice. 1998; 22(6), 575-590.

18. Effective school management (3rd ed.). London: Paul Chaman Pub Ltd; 1996.

19. Financial school management explained. Pretoria: Kagiso Tertiary; 1997.

20. The function of university education managers and CEO's in fundraising: A study of public universities with capital campaigns less than $\$ 100$ million. (Unpublished doctoral dissertation). Texas: Texas Tech University; 2004.

21. The role of the college or university education manager in institutional advancement. (Unpublished doctoral dissertation). Arizona: Northern Arizona University; 1988.

22. Effective education management. Pretoria: Kagiso Tertiary; 1991.

23. Building on relationships: A fundraising approach for community colleges. Community College Journal of Research and Practice. 2002; 26(1), 47-60.

24. A donor-focused fundraising model: An essential tool in community college foundations' toolkit. Community College Journal of Research and Practice. 2011;35(1), 99-110. 
25. Constructing the presidency: College education managers' images of their leadership roles, a comparative. Journal of Higher Education.1990; 61(6), 678-701.

26. The normative structure of college and university fundraising behaviours. Journal of Higher Education. 2010 ; 81(3), 339-365.

27. The college education manager's role in fund raising. (Department Report). Nebraska: University of Nebraska-Lincoln; 1991.

28. Entrepreneurial community college presidents: An exploratory qualitative and quantitative study. Tertiary Education and Management. 2008; 14(4), 345-370.

29. Research design: Qualitative, quantitative and mixed methods approaches. (4th ed.). Thousand Oaks, CA: Sage; 2014.

30. Applications of case study research (3rd ed.). Walnut Creek, CA: AltaMira; 2012.

31. The case study as a research method. (Unpublished paper). Austin: University of Texas; 1997.

32. The good research guide for small-scale social research projects. (3rd ed.). England: Open University Press; 2007. 